\title{
Allergen-Induced Increases in Interleukin-25 and Interleukin-25 Receptor Expression in Mature Eosinophils from Atopic Asthmatics
}

\author{
Wei Tang ${ }^{a, b}$ Steven G. Smith ${ }^{a}$ Brittany Salter ${ }^{a} \quad$ John Paul Oliveria ${ }^{a}$

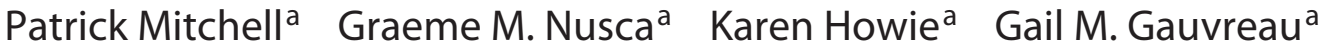 \\ Paul M. O'Byrne ${ }^{\text {a }}$ Roma Sehmi ${ }^{\text {a }}$ \\ a Division of Respirology, Department of Medicine, McMaster University, Hamilton, Ont., Canada; ${ }^{b}$ Department of \\ Respirology, Ruijin Hospital, Shanghai Jiaotong University School of Medicine, Shanghai, China
}

\section{Key Words}

Asthma · Allergen challenge · Eosinophils · Interleukin-25 . Interleukin-25 receptors

\begin{abstract}
Background: Interleukin (IL)-25 plays a pivotal role in type 2 immune responses. In a baseline cross-sectional study, we previously showed that IL-25 plasma levels and IL-25 receptor (IL-25R: IL-17RA, IL-17RB, and IL-17RA/RB) expression on mature blood eosinophils are increased in atopic asthmatics compared to normal nonatopic controls. This study investigated allergen-induced changes in IL-25 and IL-25R expression in eosinophils from asthmatics. Methods: Dual responder atopic asthmatics $(n=14)$ were enrolled in this randomized diluent-controlled crossover allergen challenge study. Blood was collected before and $24 \mathrm{~h}$ after the challenge. The surface expression of IL-25R was evaluated by flow cytometry on eosinophils and Th2 memory cells. In addition, plasma levels of IL- 25 were measured by ELISA, and functional responses to IL-25 including type 2 cytokine expression, degranulation, and the migrational responsiveness of eosino-
\end{abstract}

phils were evaluated in vitro. Results: Following the allergen but not the diluent inhalation challenge, significant increases in the expression of IL-17RB and IL-17RA/B were found on eosinophils but not on Th2 memory cells. IL-25 plasma levels and the number of eosinophils but not of Th2 memory cells expressing intracellular IL-25 increased significantly in response to the allergen but not the diluent challenge. Stimulation with physiologically relevant concentrations of IL-25 in vitro caused (i) degranulation of eosinophils (measured by eosinophil peroxidase release), (ii) enhanced intracellular expression of IL-5 and IL-13, and (iii) priming of eosinophil migration to eotaxin. IL-25 stimulated intracellular cytokine expression, and the migration of eosinophils was blocked in the presence of a neutralizing IL-25 antibody. Conclusions: Our findings suggest that the IL-25/IL-25R axis may play an important role in promoting the recruitment and proinflammatory function of eosinophils in allergic asthma.

(c) 2016 S. Karger AG, Basel

W.T., S.G.S., and B.S. are co-first authors and contributed equally to the development of this paper.

\section{KARGER}

E-Mail karger@karger.com www.karger.com/iaa
(C) 2016 S. Karger AG, Basel

$1018-2438 / 16 / 1704-0234 \$ 39.50 / 0$
Correspondence to: Dr. Roma Sehm

Division of Respirology, Department of Medicine, McMaster University 1280 Main Street West, Health Sciences Building, Rm 3U32

Hamilton, ON L8S 4K1 (Canada)

E-Mail sehmir@mcmaster.ca 


\section{Introduction}

Asthma is a disease of the airways characterized by reversible airflow obstruction, airway inflammation, and airway hyperresponsiveness (AHR) $[1,2]$. Tissue eosinophilia and T-helper (Th)2 cells are predominant components of the airway inflammatory cell infiltrate in allergic asthmatics [3]. Treatment strategies that decrease airway eosinophilia in asthmatics significantly improve asthma control. The central role of eosinophils in the pathogenesis of asthma underscores the need to investigate the factors that mobilize and activate this cell in asthma exacerbations.

Interleukin (IL)-25 (IL-17E) is a proinflammatory cytokine that belongs to the IL-17 cytokine family and, unlike other members of the IL-17 family, it plays a pivotal role in the maintenance of type 2 immune responses [4]. IL-25 induces the release of type 2 cytokines, i.e. IL- 4 and IL-5, from Th2 memory cells when costimulated with either anti-CD3 or anti-CD28 antibodies [5] and in combination with thymic stromal lymphopoietin activates dendritic cells [6]. In mice, administration of IL-25 stimulates eosinophilic inflammation and AHR that is STAT6/IL-13 axis dependent [7], and inhibition of IL-25 attenuates the development of ovalbumin-induced AHR [8]. In combination with the epithelial derived cytokine IL-33, IL-25 can promote the expansion of group 2 innate lymphoid cells which are involved in the early initiation of type $2 \mathrm{im}$ mune responses [9]. IL-25 directly activates eosinophils by upregulating the expression of ICAM-1, stimulating the release of proinflammatory chemokines such as monocyte chemoattractant protein-1, IL-8, macrophage inflammatory protein-1, and IL-6 and delaying apoptosis $[10,11]$.

The IL- 25 receptor consists of 2 subunits, i.e. IL-17RA (signaling subunit) and IL-17RB (specific cytokine-binding subunit), that form the functional receptor IL-17RA/ RB [12]. In a baseline cross-sectional study, we previously showed that the expression of IL-17RA and IL-17RB on mature eosinophils and the plasma level of IL-25 are significantly greater in asymptomatic allergic asthmatics than in atopic nonasthmatics and nonatopic normal subjects [13]. Although an important role for IL-25 has been established in animal models of allergic disease $[8,14]$ and in in vitro studies $[5,6,15]$, the kinetics of IL-25 production and the expression of IL-25 receptor components on innate and adaptive immune cells during allergic inflammatory responses in human asthmatics have not been investigated to date.

In this study, we examined the kinetics of IL-25 and IL-25R expression on mature eosinophils and Th2 mem- ory cells in the blood of asthmatic subjects following an allergen inhalation challenge. We hypothesized that the level of IL-25 protein and its receptor expression on eosinophils would increase following allergen inhalation. The effect of IL-25 on eosinophil cytokine generation, degranulation, and migrational responses was investigated with a view to understanding the role of IL-25 in orchestration of the development of tissue eosinophilia and proinflammatory responses in allergic asthma.

\section{Materials and Methods}

\section{Study Design}

Fourteen consenting subjects (aged 19-52 years) with mild allergic asthma who were steroid naive and used $\beta_{2}$-agonists intermittently were enrolled in this study. All of the subjects were nonsmokers. Mild allergic asthma was defined based on (i) a skin prick test positive to at least one aeroallergen, where skin prick positivity was defined as a $2 \times 2 \mathrm{~mm}$ wheal together with a positive histamine response and a negative diluent response, and (ii) spirometry showing a forced expiratory volume in $1 \mathrm{~s}\left(\mathrm{FEV}_{1}\right) \geq 70 \%$ predicted. Spirometry was conducted according to American Thoracic Society guidelines and normalized using NHANES III reference equations [16]. Allergen and diluent inhalation challenges were carried out, as previously described [17]. All subjects demonstrated a dual airway response to the inhaled allergen, i.e. a decrease in $\mathrm{FEV}_{1} \geq 20 \%$ within the first $3 \mathrm{~h}$ postallergen and a second decrease in $\mathrm{FEV}_{1} \geq 15 \%$ 3-7 h postallergen. Skin testing showed that the majority of the subjects were sensitized to more than one common aeroallergen. The allergen selected for inhalation yielded the largest skin wheal during the skin prick test and/ or caused asthma symptoms following regular exposure. The characteristics of the subjects are summarized in table 1 . This study was approved by the Hamilton Health Science Regional Ethics Board.

In a diluent-controlled allergen challenge crossover study, allergen or diluent challenges were randomized with a 4-week washout period. Subjects attended the laboratory for 3 consecutive visits. On visit 1, a medical history and physical examination were performed and the subjects underwent a skin prick test, spirometry, and a methacholine inhalation challenge [18]. On visit 2, the subjects underwent an inhalation challenge and spirometry was measured hourly up to $7 \mathrm{~h}$ after the challenge. On visit 3 , the spirometry and methacholine challenge were conducted $24 \mathrm{~h}$ after the inhalation challenge.

\section{Cell Preparation and Immunofluorescence Staining}

Whole blood was collected in EDTA tubes, red blood cells were lysed using a lysis solution, and white blood cells were resuspended in FACS buffer (PBS supplemented with $0.1 \%$ sodium azide and $0.5 \%$ bovine serum albumin). To determine the expression of the IL-25 receptor on eosinophils, cells were stained with V450CD45, APC-CD16, FITC-IL-17RA, PE-IL-17RB or FITC-IgG1, and the PE-IGg2B isotype. To quantify the expression of this receptor, Th2 memory cells were stained with V450-CD3, Alexa Fluor 700-CD4, APC-CRTH2 or the APC-IgG1 isotype control, FITC-IL-17RA, PE-IL-17RB or FITC-IgG1, and the PE-conjugat- 
Table 1. Baseline subject characteristics

\begin{tabular}{|c|c|c|c|c|c|c|c|}
\hline \multirow[t]{2}{*}{ Sex } & \multirow{2}{*}{$\begin{array}{l}\text { Age, } \\
\text { years }\end{array}$} & \multirow{2}{*}{$\begin{array}{l}\mathrm{FEV}_{1}, \% \\
\text { predicted }\end{array}$} & \multirow{2}{*}{$\begin{array}{l}\mathrm{PC}_{20} \text { before the } \\
\text { methacholine } \\
\text { challenge, } \mathrm{mg} / \mathrm{ml}\end{array}$} & \multirow{2}{*}{$\begin{array}{l}\text { Allergen } \\
\text { inhaled }\end{array}$} & \multicolumn{2}{|c|}{ Decrease in $\mathrm{FEV}_{1}, \%$} & \multirow{2}{*}{$\begin{array}{l}\mathrm{PC}_{20} \text { after the } \\
\text { methacholine } \\
\text { challenge, } \mathrm{mg} / \mathrm{ml}\end{array}$} \\
\hline & & & & & EAR & LAR & \\
\hline M & 19 & 81 & 0.31 & Cat & 35 & 31 & 0.16 \\
\hline M & 25 & 114 & 10.31 & HDM & 22 & 31 & 0.92 \\
\hline $\mathrm{F}$ & 19 & 117 & 20.80 & Cat & 22 & 18 & 5.97 \\
\hline F & 49 & 97 & 1.07 & HDM & 31 & 37 & 1.24 \\
\hline M & 44 & 73 & 16.00 & Grass & 41 & 22 & 3.31 \\
\hline $\mathrm{F}$ & 41 & 94 & 0.83 & Ragweed & 42 & 16 & 0.38 \\
\hline $\mathrm{F}$ & 47 & 90 & 0.60 & Cat & 47 & 20 & 0.43 \\
\hline $\mathrm{F}$ & 20 & 92 & 3.19 & Tree & 24 & 36 & 3.26 \\
\hline M & 52 & 100 & 6.99 & HDM & 36 & 18 & 5.74 \\
\hline M & 27 & 97 & 2.71 & Ragweed & 42 & 16 & 2.7 \\
\hline F & 21 & 98 & 16.00 & Horse & 40 & 28 & 1.33 \\
\hline $\mathrm{F}$ & 19 & 80 & 5.82 & Ragweed & 29 & 23 & 2.81 \\
\hline M & 49 & 90 & 16.00 & HDM & 33 & 25 & 0.11 \\
\hline $\mathrm{F}$ & 24 & 116 & 0.38 & HDM & 23 & 25 & 0.36 \\
\hline $\mathrm{F}$ & 25 & 108 & 15.48 & HDM & 38 & 21 & 4.26 \\
\hline
\end{tabular}

All subjects had a positive skin prick test, an $\mathrm{FEV}_{1} \geq 70 \%$ predicted, and a dual airway response to the inhaled allergen, i.e. a decrease in $\mathrm{FEV}_{1} \geq 15 \%$ within the first $2 \mathrm{~h}$ and a second decrease $3-7 \mathrm{~h}$ after the allergen challenge. $\mathrm{HDM}=$ House dust mite.

ed mouse IGg2B isotype. To determine the intracellular cytokine expression, cells were prestained with either V450-CD45 and APC-CD16 or V450-CD3, Alexa Fluor 700-CD4, and APCCRTH2 and resuspended in $4 \%$ paraformaldehyde for $10 \mathrm{~min}$, permeabilized with detergent ( $1 \%$ saponin and $0.05 \% \mathrm{NaN}_{3}$ in Hanks' balanced salt solution), and stained with FITC-conjugated mouse anti-human IL-25 or FITC-IgG1 (R\&D Systems, USA) (30 min at $20^{\circ} \mathrm{C}$ ) and then fixed in $1 \%$ paraformaldehyde prior to flow cytometric acquisition.

\section{Immunoassay for Quantitative Measurement of IL-25 in \\ Plasma}

Measurement of IL-25 in plasma was performed using a commercially available ELISA (PeproTech Inc., N.J., USA) as described previously by our group and others $[13,19]$.

Eosinophil Degranulation Assay: Eosinophil Peroxidase Assay

Peripheral blood $(100 \mathrm{ml})$ drawn from atopic subjects was layered on AccuPrep. Following centrifugation, the granulocyte layer was harvested and eosinophils were isolated using MACS column CD16+ depletion (Miltenyi Biotech, Calif., USA). The cell purity of the eosinophils was $>95 \%$, with a viability $>90 \%$. Enriched cells were cultured in a 24 -well plate $\left(1 \times 10^{6} / \mathrm{ml}\right)$ in RPMI-complete with or without a previously optimized concentration of IL-25 ( $1 \mathrm{ng} / \mathrm{ml}$; R\&D Systems) and treated with the isotype control or anti-IL-25 (0.5 $\mu \mathrm{g} / \mathrm{ml}$; R\&D Systems) for $2 \mathrm{~h}$ prior to the end of the assay. The cells were then resuspended in $1 \%$ paraformaldehyde and the supernatant was collected for measurement of eosinophil peroxidase (EPX) by ELISA (Cloud Clone Corp., USA).

\section{IL-25-Stimulated Type 2 Cytokine Expression}

Enriched populations of eosinophils were cultured in 24-well plates $\left(1 \times 10^{6} / \mathrm{ml}\right)$ in RPMI-complete with or without IL-25 for $18 \mathrm{~h}$ in the presence or absence of anti-IL-25 (0.01, 0.1 , and $0.5 \mu \mathrm{g} /$ $\mathrm{ml}$ ). Monensin, a Golgi blocker (BioLegend, USA), was added $6 \mathrm{~h}$ prior to the completion of incubation. Cell viability was assessed via trypan blue staining. Cells were harvested following incubation and immunostained for intracellular cytokines as described above and acquired by flow cytometry. The cell purity of the eosinophils was $>95 \%$, with a viability $>90 \%$.

Mature Eosinophil Migration: Micro Boyden Chamber Assay

Purified eosinophils in RPMI-complete were incubated for $2 \mathrm{~h}$ with $1 \mathrm{pg} / \mathrm{ml}$ of IL-25 or with diluent. IL-25 activity was blocked by preincubation with IL- 25 neutralizing antibody $(2.4 \mathrm{ng} / \mathrm{ml}, 20$ min). Migration was assessed using 48-well Boyden chambers, as previously described [20, 21]. Eotaxin (1 nM; R\&D Systems) was added to the lower wells, and eosinophils $\left(3 \times 10^{6}\right.$ cells $\left./ \mathrm{ml}\right)$ were added to the upper well. The number of eosinophils was quantified from 10 random fields at the leading edge using a light microscope at a $\times 40$ magnification.

\section{Flow Cytometry Acquisition}

Data were acquired using a 15-color LSR II flow cytometer equipped with 3 lasers (Becton Dickinson Instrument Systems, Canada) with FACSDiva software (Becton Dickinson Biosciences, Canada). Data analyses were performed using FlowJo software version 9.3.2 (Tree Star, USA) to determine the IL-25 receptor component expression and intracellular IL-25 levels [for gating strategy details, 
Table 2. Lung function and sputum details of the subjects

\begin{tabular}{|c|c|c|}
\hline & $\begin{array}{l}\mathrm{Ag} \\
\text { challenge }\end{array}$ & $\begin{array}{l}\text { Diluent } \\
\text { challenge }\end{array}$ \\
\hline \multicolumn{3}{|l|}{ Early-phase response, \% change } \\
\hline in $\mathrm{FEV}_{1}$ & $-33.67(2.12)^{b}$ & $-3.4(1.51)$ \\
\hline \multicolumn{3}{|l|}{ Late-phase response, $\%$ change } \\
\hline \multicolumn{3}{|l|}{ Methacholine $\mathrm{PC}_{20}, \mathrm{mg} / \mathrm{ml}$} \\
\hline Pre-Ag & $7.77(1.88)$ & $6.36(2.39)$ \\
\hline $24 \mathrm{~h}$ post-Ag & $2.20(0.51)^{\mathrm{a}}$ & $6.30(2.40)$ \\
\hline \multicolumn{3}{|l|}{ Total sputum cells, $\mathrm{n} \times 10^{6} \mathrm{cell} / \mathrm{s} / \mathrm{ml}$} \\
\hline Pre-Ag & $3.62(0.64)$ & $5.02(1.16)$ \\
\hline $24 \mathrm{~h}$ post $\mathrm{Ag}$ & $6.59(1.27)^{\mathrm{a}}$ & $4.48(1.07)$ \\
\hline \multicolumn{3}{|l|}{ Sputum eosinophils, \% } \\
\hline Pre-Ag & $4.68(1.63)$ & $1.5(0.49)$ \\
\hline $24 \mathrm{~h}$ post-Ag & $12.26(2.68)^{\mathrm{a}, \mathrm{b}}$ & $2.79(1.06)$ \\
\hline \multicolumn{3}{|l|}{$\begin{array}{l}\text { Blood eosinophils, } \mathrm{n} / 10^{9} \text { white } \\
\text { blood cells }\end{array}$} \\
\hline Pre-Ag & $38(6)$ & $88(27)$ \\
\hline $24 \mathrm{~h}$ post- $\mathrm{Ag}$ & $64(9)^{\mathrm{a}}$ & $94(31)$ \\
\hline
\end{tabular}

Values are presented as geometric means (SEM). Significant differences were found for early- and late-phases responses, methacholine $\mathrm{PC}_{20}$, total sputum cells, and sputum and blood eosinophils after the allergen challenge. $\mathrm{Ag}=$ Allergen; $\mathrm{PC}_{20}=$ provocative concentration of methacholine causing a $20 \%$ decrease in the $\mathrm{FEV}_{1} \cdot{ }^{\mathrm{a}} \mathrm{p}<0.05$ compared to baseline. ${ }^{\mathrm{b}} \mathrm{p}<0.05$ compared to the diluent.

see online supplementary figure E1 for mature eosinophils (identified as CD45+ 16-) and online supplementary figure E2 for Th2 memory cells (identified as CD3+CD4+CRTH2+ cells); for all online suppl. material, see www.karger.com/doi/10.1159/000449248] (the strategy is also described in the paper by Tang et al. [13]).

\section{Statistical Analysis}

Statistical analysis was performed using GraphPad Prism 5 software (GraphPad Software Inc., USA). Normally distributed data are expressed as means \pm SEM. The concentration of methacholine required to achieve a $20 \%$ decrease in $\mathrm{FEV}_{1}\left(\mathrm{PC}_{20}\right)$ is expressed as a geometric mean and a geometric standard error of the mean. For fluctuations in IL-25 receptor expression on eosinophils and Th2 memory cells and all in vitro experiments, a repeated-measures ANOVA was used. Post hoc comparisons were performed using Tukey's multiple comparisons tests. $\mathrm{p}<0.05$ was considered statistically significant for all analyses.

\section{Results}

\section{Airway Physiology and Airway Inflammation}

The characteristics of the subjects at baseline are presented in table 1 . All subjects had a significant decrease in $\mathrm{FEV}_{1}$ from baseline during the early asthmatic response
Table 3. Th2 memory cells

\begin{tabular}{lcc}
\hline & $\begin{array}{l}\text { Ag } \\
\text { challenge }\end{array}$ & $\begin{array}{l}\text { Diluent } \\
\text { challenge }\end{array}$ \\
\hline Blood Th2 memory cells & $25(7)$ & $14(3)$ \\
$\quad$ Pre-Ag & $17(6)^{\mathrm{a}}$ & $7(2)$ \\
24 h post-Ag & & \\
\hline IL-17RA+ Th2 memory cells & $24,575(6,668)$ & $131,876(19,209)$ \\
Pre-Ag & $7,452(1,322)$ & $17,337(5,544)$ \\
24 h post-Ag & $17,221(4522)$ & $53,485(6,638)$ \\
\hline IL-17RB+ Th2 memory cells & $10,911(3,495)$ & $5,890(1,176)$ \\
Pre-Ag & $13,278(3,423)$ & $44,426(6,252)$ \\
24 h post-Ag & $9,099(3,374)$ & $3,413(586)$ \\
\hline IL-17RA/IL-17RB+ Th2 memory cells & \\
Pre-Ag & & \\
24 h post-Ag & $29,246(8,308)$ & $15,854(2,309)$ \\
\hline IL-25+ Th2 memory cells & $24,983(6,255)$ & $7,427(1,866)$ \\
Pre-Ag &
\end{tabular}

Values are presented as mean numbers per $10^{6}$ white blood cells (SEM). Before and after the allergen and diluent challenges, changes in absolute numbers of Th2 memory cells expressing the IL-25 receptor and intracellular IL-25 were observed. Ag = Allergen. ${ }^{\mathrm{a}} \mathrm{p}<0.05$ compared to baseline.

and the late asthmatic response compared to diluent inhalation (table 2). There was a significant decrease in $\mathrm{PC}_{20}$ and an increase in sputum eosinophils $24 \mathrm{~h}$ after the allergen challenge but not after the diluent challenge (table 2). In addition, there was a significant increase in the absolute number of mature eosinophils in blood when baseline levels were compared to levels $24 \mathrm{~h}$ after the allergen challenge $\left(38 \pm 6 \times 10^{9}\right.$ to $64 \pm 9 \times 10^{9}$ cells $\left./ \mathrm{ml} ; \mathrm{p}<0.05\right)$ but not after the diluent inhalation challenge (table 2 ).

\section{Allergen-Induced Changes in IL-25 Receptor Expression}

In blood, there was a significant increase in the number of mature eosinophils expressing IL-17RB (7,426 \pm 2,824 to $19,446 \pm 5,593$ cells $/ 10^{6}$ white blood cells, $\mathrm{p}<$ $0.01)$ and IL-17RA/RB $(4,508 \pm 1,360$ to $9,025 \pm 3,166$ cells $/ 10^{6}$ white blood cells, $\left.\mathrm{p}<0.001\right)$ but not IL-17RA when preallergen levels were compared to levels $24 \mathrm{~h}$ after the allergen inhalation challenge (fig. 1a-c). In contrast, Th2 memory cells in blood displayed no significant allergen-induced changes in IL-25 surface receptor expression (table 3). 


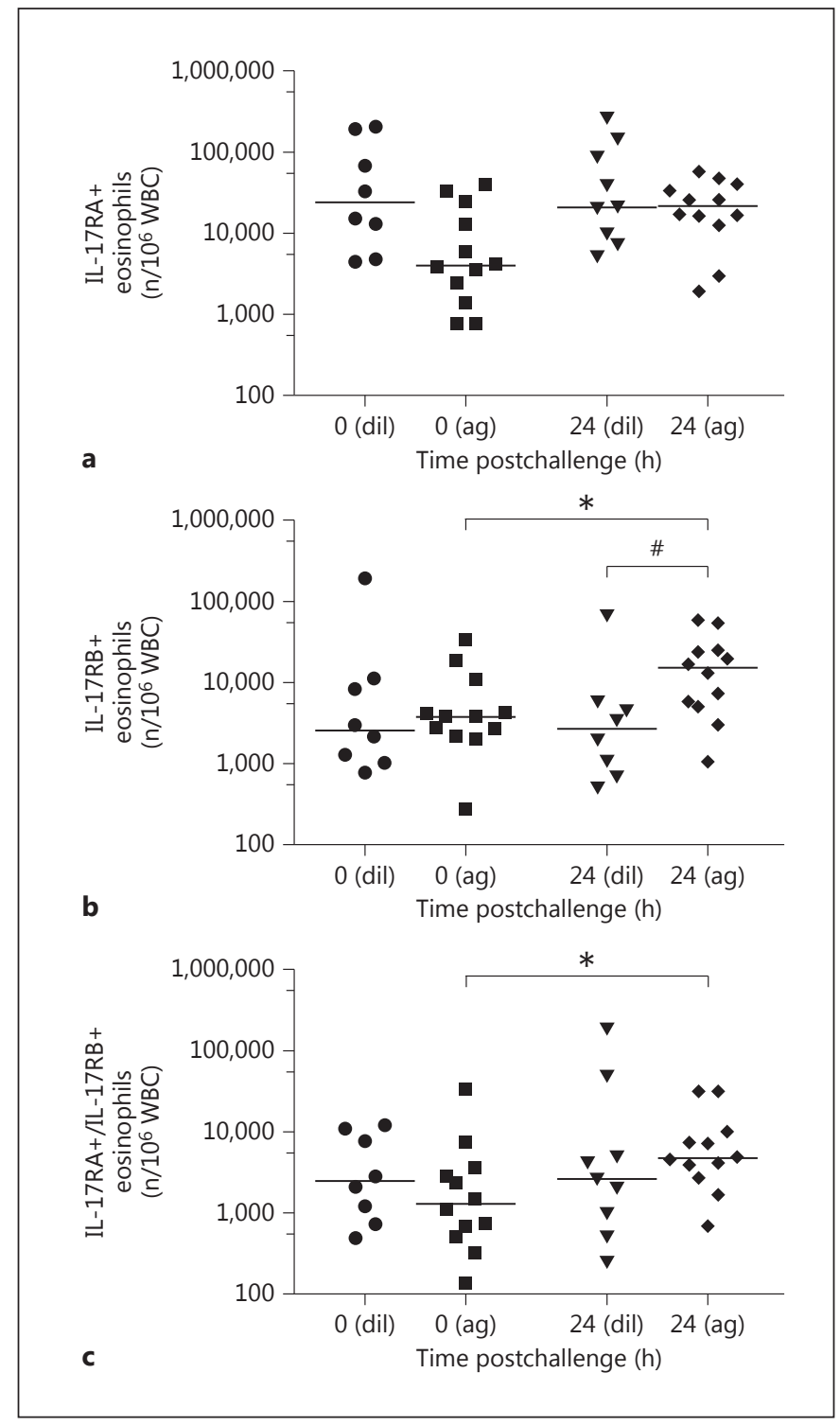

Fig. 1. Allergen-induced changes in components of IL-25 receptor expression on mature eosinophils, i.e. (a) IL-17RA+, (b) IL$17 \mathrm{RB}+$, and (c) IL-17RA/RB+, in mild allergic asthmatics following a diluent or allergen challenge. The absolute numbers of IL$17 \mathrm{RB}+$ and IL-17RA/RB+ eosinophils in blood increased $24 \mathrm{~h}$ after the allergen challenge but not $24 \mathrm{~h}$ after the diluent challenge. Data are presented for 10 subjects and horizontal bars represent the median value. ${ }^{*} \mathrm{p}<0.05$. WBC $=$ White blood cells; ag = allergen; dil $=$ diluent.

\section{Allergen-Induced Changes in Plasma and Intracellular IL-25 Levels}

By ELISA, blood plasma IL-25 showed significant increases when preallergen levels $(650 \pm 45 \mathrm{pg} / \mathrm{ml})$ were compared to levels at $7 \mathrm{~h}(851 \pm 43 \mathrm{pg} / \mathrm{ml} ; \mathrm{p}<0.001)$ and

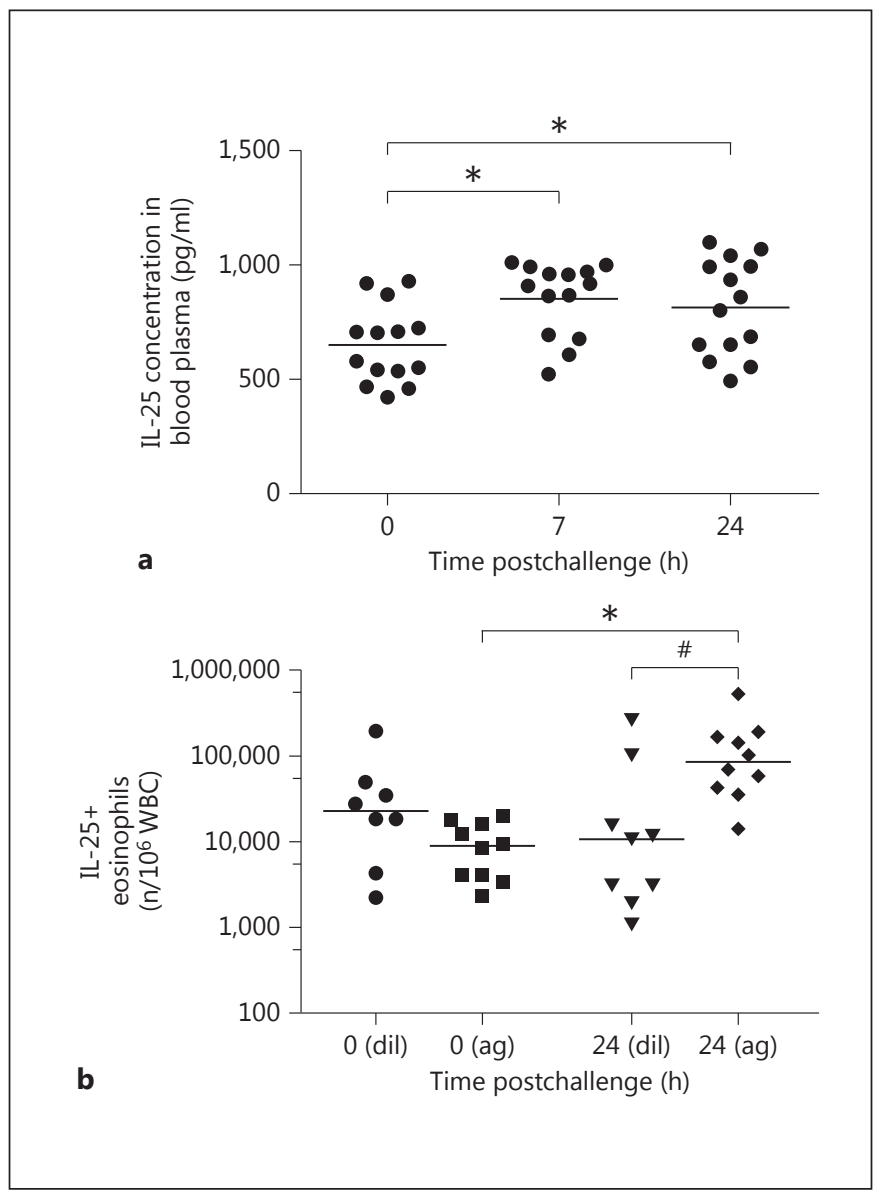

Fig. 2. Allergen-induced changes in IL-25 levels in (a) blood plasma and (b) eosinophil intracellular levels from 14 and 10 mild asthmatics, respectively. The blood plasma levels of IL-25 increased 7 and $24 \mathrm{~h}$ after the allergen challenge. Significant changes in intracellular levels of IL-25 were detected in mature eosinophils $24 \mathrm{~h}$ after the allergen challenge but not after the diluent challenge. For each data set, the horizontal bars represent the median value. ${ }^{*} \mathrm{p}<0.05$ compared to baseline. ${ }^{*} \mathrm{p}<0.05$ compared to the diluent. $\mathrm{WBC}=$ White blood cells; ag = allergen; dil = diluent.

$24 \mathrm{~h}$ postallergen challenge $(813 \pm 56 \mathrm{pg} / \mathrm{ml}, \mathrm{p}<0.001 ;$ fig. 2a).

In addition, the absolute number of eosinophils in blood expressing intracellular IL-25 increased significantly when preallergen levels were compared to levels at 24 h postallergen $(10,398 \pm 1,909$ to $147,684 \pm 46,222$ cells $/ 10^{6}$ white blood cells, $\mathrm{p}<0.05$ ) but not after the diluent challenge (fig. 2b). In contrast, Th2 memory cells from blood displayed no significant allergen-induced changes in levels of intracellular IL-25 expression (table 3). 


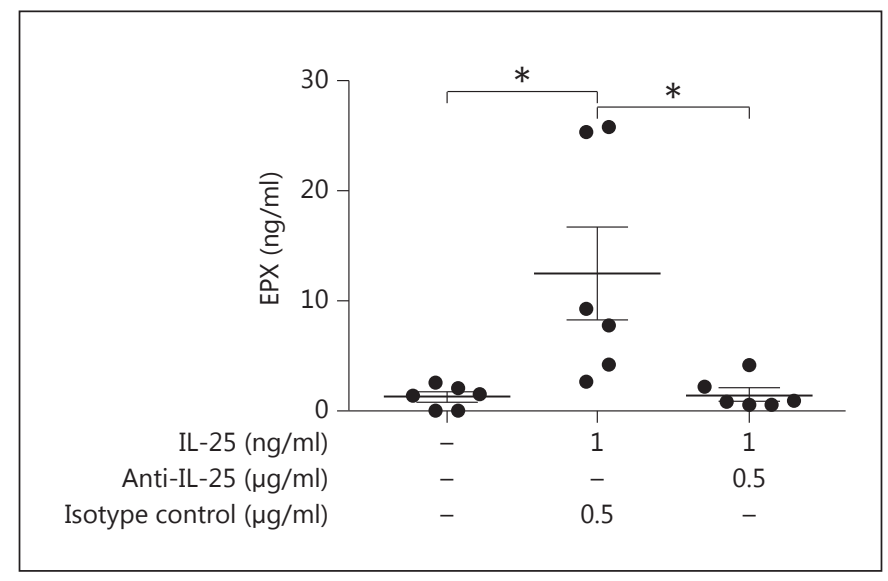

Fig. 3. IL-25 stimulated degranulation by mature eosinophils in vitro. Blood eosinophils from atopic asthmatics were stimulated with diluent or IL-25 (1 ng/ml, $2 \mathrm{~h})$ in the presence or absence of a neutralizing antibody to IL-25 $(0.5 \mu \mathrm{g} / \mathrm{ml})$. EPX levels in the supernatants were assessed by ELISA. Data are presented for 6 subjects, and the horizontal bars represent the median. ${ }^{*} \mathrm{p}<0.05$ for comparisons between groups.

\section{IL-25-Induced Degranulation of EPX from Mature Eosinophils}

Stimulation with IL-25 $(1 \mathrm{ng} / \mathrm{ml})$ for $2 \mathrm{~h}$ significantly increased the release of EPX by mature eosinophils compared to the diluent control ( $1.26 \pm 0.4$ to $12.5 \pm 4.2 \mathrm{ng} /$ $\mathrm{ml}, \mathrm{p}<0.05$; fig. 3$)$. This effect was reduced significantly in the presence of an optimal dose of anti-IL-25 $(0.5 \mu \mathrm{g} /$ $\mathrm{ml}, 1.5 \pm 0.6 \mathrm{ng} / \mathrm{ml}, \mathrm{p}<0.05$; fig. 3 ).

\section{IL-25 Induces Intracellular Th2 Cytokine Expression in Mature and Immature Eosinophils}

There was a significant increase in the proportion of eosinophils expressing intracellular IL-5 and IL-13 following stimulation with IL-25 (18 h,optimal at 10 and $1 \mathrm{ng} / \mathrm{ml}$, respectively; fig. $4 \mathrm{a}, \mathrm{b}$, respectively). This effect was inhibited in the presence of anti-IL-25 optimally at 0.01 and $0.1 \mu \mathrm{g} / \mathrm{ml}$, respectively (fig. $5 \mathrm{a}, \mathrm{b}$ ).

\section{IL-25 Primes the Migration of Mature and Immature}

Eosinophils in vitro

IL-25 (1-1,000 pg/ml) over a wide concentration range did not directly stimulate the migration of mature eosinophils in vitro. However, pre-exposure to low doses of IL-25 (optimal at $1 \mathrm{pg} / \mathrm{ml}$ ) significantly enhanced the subsequent migrational response of mature eosinophils to eotaxin ( $1 \mathrm{nM}, 36 \pm 3$ vs. $69 \pm 5$, p < 0.05; fig. 6). Pretreatment with an IL-25 neutralizing antibody $(2.4 \mathrm{ng} /$ $\mathrm{ml}$ ) significantly inhibited the priming effect of IL-25

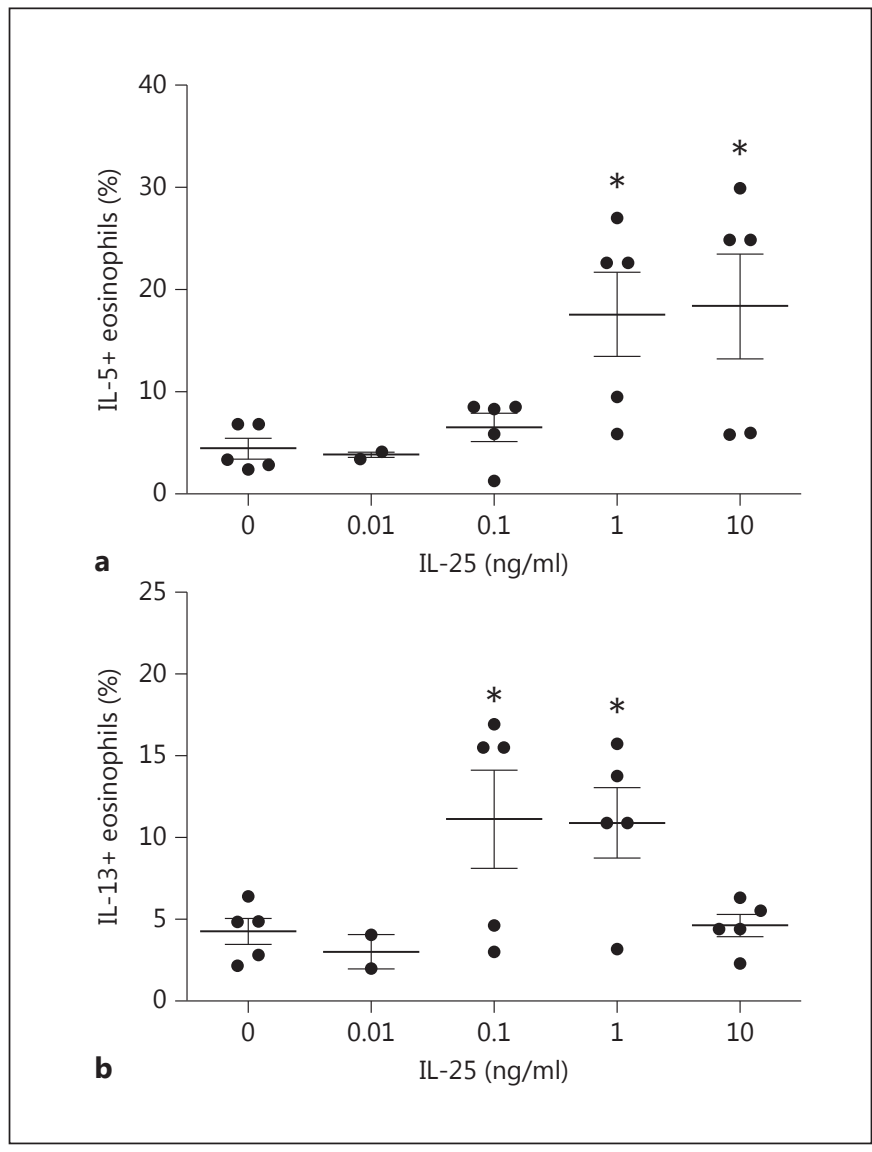

Fig. 4. IL-25 stimulation of mature eosinophils induced intracellular type 2 cytokine expression in vitro. Eosinophils from atopic asthmatics were stimulated for $18 \mathrm{~h}$ in vitro with IL-25 and assessed for intracellular expression of (a) IL-5 and (b) IL-13 by flow cytometry. IL-25 stimulated a significant increase in the intracellular levels of both cytokines in mature eosinophils. Data are presented for 6 subjects, and horizontal bars represent the median. $* \mathrm{p}<0.05$ compared to the diluent.

$(1 \mathrm{pg} / \mathrm{ml})$ on the eotaxin-stimulated migration of mature eosinophils (fig. 6). The priming effect of IL-25 was not observed with suboptimal concentrations of other potent eosinophil chemoattractants including RANTES, MCP1 , and SDF-1a (see online suppl. table E1).

\section{Discussion}

This study shows that following an allergen inhalation challenge, in dual responder asthmatics, IL-25 plasma levels are increased and IL-25 receptor components are upregulated on the surface of mature eosinophils. In ad- 


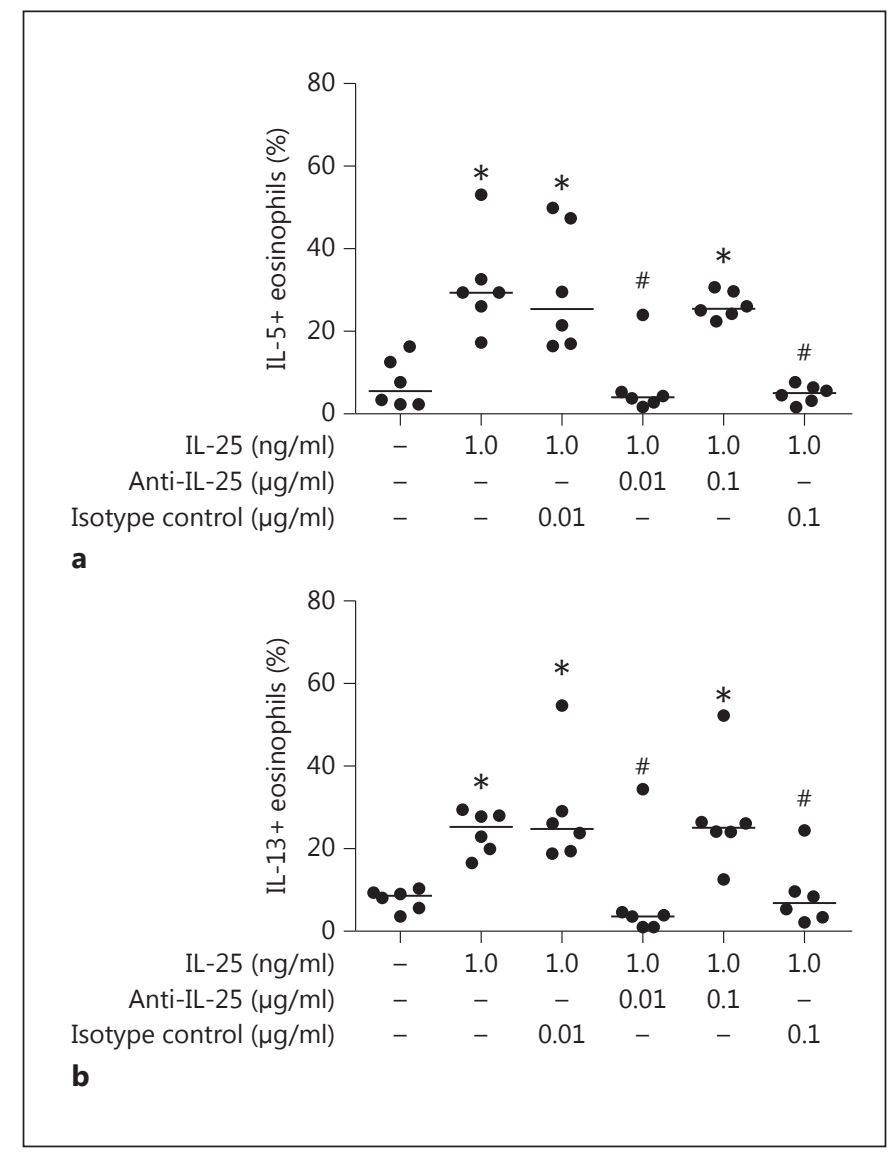

Fig. 5. Neutralization of IL-25 inhibits IL-25-induced stimulation of mature eosinophils in vitro. Type 2 intracellular cytokine expression. Eosinophils from atopic asthmatics were stimulated for $18 \mathrm{~h}$ in vitro with IL-25 in the presence of anti-IL-25 which attenuated the intracellular expression of (a) IL-5 and (b) IL-13 significantly. Data are presented for 6 subjects, and horizontal bars represent the median. ${ }^{*} \mathrm{p}<0.05$ compared to the diluent. ${ }^{*} \mathrm{p}<0.05$ compared to the isotype control.

dition, there were increases in intracellular levels of IL-25 in circulating eosinophils $24 \mathrm{~h}$ after the allergen challenge. Short-term stimulation with physiologically relevant doses of IL-25 $(1,000 \mathrm{pg} / \mathrm{ml})$ induced mature eosinophil degranulation as measured by EPX release. Overnight stimulation with IL-25 (100-1,000 pg/ml) was shown to promote intracellular type 2 cytokine expression by eosinophils, which was inhibited in the presence of a neutralizing antibody to IL-25. In an in vitro migration assay, lower doses of IL-25 (1 pg/ml) primed migrational responses of eosinophils to the eosinophil chemoattractant eotaxin. Our results suggest that upregulation of IL-25 receptor expression on eosinophils may

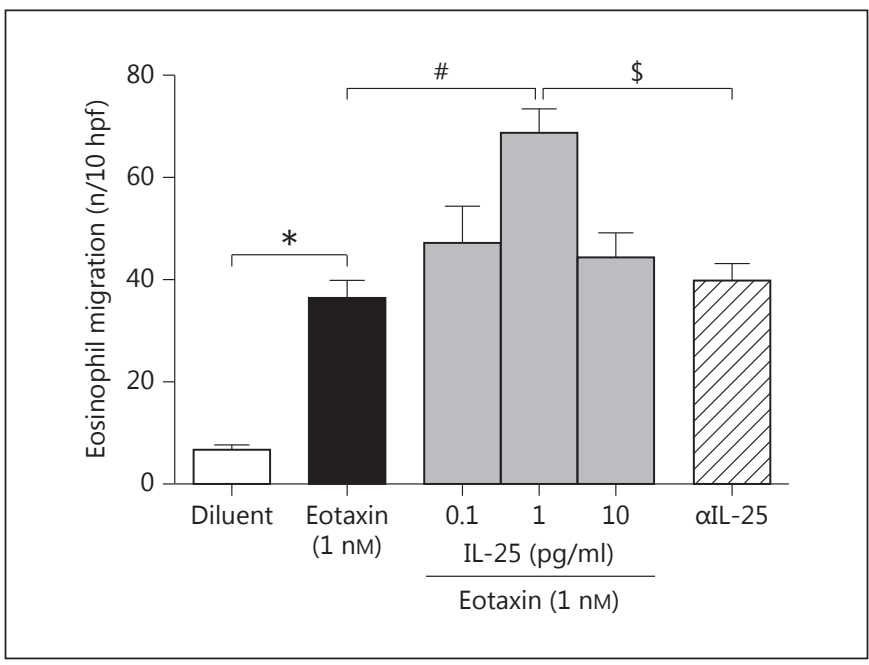

Fig. 6. IL-25 primes eosinophil migrational responses in vitro. Preincubation with IL-25 primed the eotaxin-induced migration of eosinophils, which was attenuated in the presence of IL- 25 neutralizing antibody in vitro. Data are presented for 7 subjects, and horizontal bars represent the median. ${ }^{*} \mathrm{p}<0.05$ compared to the diluent. ${ }^{\#} \mathrm{p}<0.05$ compared to the chemoattractant alone. ${ }^{\$} \mathrm{p}<0.05$ compared to IL-25-primed migration. $\mathrm{hpf}=$ High-power fields.

mediate an increased sensitivity to IL-25, which in turn may enhance cell recruitment and proinflammatory activity within the airways in response to allergen exposure in allergic asthmatics.

The proinflammatory effect of IL-25 has been well demonstrated in animal models. Exogenous administration of IL-25 or transgenic expression induces type 2 asthma-like inflammation in the airways in mice $[22,23]$. Conversely, anti-IL-25 antibody reduces airway inflammation in animal models of allergic asthma $[8,14]$. IL-25 has been shown to link innate and adaptive immunity by enhancing type 2 cytokine production including IL- 5 and IL-13 [4]. The biological effects of IL-25 are mediated by the IL-25 receptor, composed of the subunits IL-17RA and IL-17RB, which combine to form the functional receptor for IL-25 (IL-17RA/IL-17RB) [12]. IL-25 is the high-affinity ligand for IL-17RB $[24,25]$, and in a previous study we showed that the IL-25 receptor expression on eosinophils is higher in allergic asthmatics compared to atopic nonasthmatic and normal subjects [13]. In this study, we found that the expression of IL-17RB and the functional receptor (IL-17RA/RB) on peripheral blood eosinophils was significantly increased $24 \mathrm{~h}$ after the allergen challenge but not after the diluent challenge. This is consistent with a report showing increased expression 
of IL-25 and its receptor in the bronchial mucosa of asthmatics at $24 \mathrm{~h}$ postallergen, where the majority of IL-25 and IL-25R immune-reactive cells were eosinophils [26]. Evidence shows that eosinophils are a source of IL-25 [5, 18]. In agreement with this, our results showed a significant increase in intracellular staining of IL-25 in eosinophils $24 \mathrm{~h}$ after allergen inhalation. This supports the view that there is a dynamic release of IL-25 from eosinophils during allergic inflammatory responses.

Th2 memory cells are also important for the promotion of allergic inflammation. In an in vitro study, IL-25 stimulated Th2 memory cell expansion and type 2 cytokine production when costimulated with thymic stromal lymphopoietin [6]. IL-25 can also synergistically induce the release of type 2 cytokines from anti-CD3 and antiCD28 antibodies costimulated with memory Th2 cells. This costimulation upregulates the surface expression of IL-25R on Th2 cells [5]. In the present study, there was no difference in IL-25R expression on Th2 memory cells in the circulation $24 \mathrm{~h}$ after the allergen challenge. This may be explained by activated Th 2 cells, with a higher expression percentage of IL-25R, being recruited into the airway after allergen inhalation. Consistent with this, a previous study showed increased expression of the IL-25 receptor on CD3+ cells in the bronchial mucosa of asthmatic patients after an allergen challenge [26]. Although this was not observed on blood-derived Th2 memory cells in the current study at $24 \mathrm{~h}$ postallergen, a transient increases in receptor expression may have occurred at the earlier time point of $7 \mathrm{~h}$ postallergen which was not assessed.

A limitation of this study is that analyses of freshly isolated $\mathrm{T}$ cells for intracellular cytokine staining without further in vitro stimulation may have precluded detection of the true cytokine synthetic capability of Th2 memory cells postallergen. In addition, sputum samples were not analyzed to assess changes within the airways where Th2 memory cells may have homed to following the allergen inhalation challenge.

Previous cross-sectional studies have shown increases in plasma levels of IL-25 in allergic asthmatics compared to normal subjects $[13,27]$. The present study, demonstrated for the first time, an increase in plasma levels of IL-25 following an allergen inhalation challenge. Although the increases in IL-25 plasma levels did not correlate with the increases in IL-17RB or IL-17RA expression on any of the cell populations assessed in this study, the elevated plasma levels of IL-25 may partially explain the increased expression of IL-17RB on eosinophils as IL25 has been shown to upregulate IL-17RB expression on eosinophils in vitro [10]. IL-25 levels in sputum supernatants were undetectable by ELISA likely due to the proteolytic effect of the reagents used during sputum processing. However, circulating IL-25 levels maybe a surrogate marker for airway activation, as a recent reported showed that IL-25 plasma levels correlated with airway epithelial IL-25 expression at the protein and transcript level in allergic asthmatics [27]. Furthermore, higher plasma IL-25 levels were associated with greater bronchial eosinophilia, lung function and airway hyperreactivity, highlighting a central role for IL-25 in the pathobiology of allergic asthma.

Mature eosinophils have been shown to be significant sources of granule proteins, including EPX, MPB, and $\mathrm{EPO}$, which cause damage to the airway epithelium [28, 29]. In addition, eosinophils are also important sources of type 2 cytokines, which can further contribute to proinflammatory processes in asthma [30-32]. Our data show that IL-25 can stimulate EPX release by mature eosinophils and increased IL-5 and IL-13 expression. In addition, our data show that, although IL-25 did not stimulate direct chemotactic responses, pre-exposure to IL-25 enhanced the subsequent migrational response of eosinophils to a potent chemoattractant, such as eotaxin [33]. We propose that activation of eosinophils during an allergic inflammatory response stimulates autologous IL25 production which at low local concentrations primes the migrational responsiveness of the cells and at higher concentrations stimulates degranulation.

In summary, the results of this study suggest that IL-25 may play a role in the pathogenesis of allergen-induced airway responses in asthmatic subjects through upregulation of eosinophil recruitment and effector function. We propose that IL-25 neutralization may be a potential therapeutic target for the attenuation of allergen-induced asthmatic responses mediated by airway eosinophilia.

\section{Acknowledgements}

The authors would like to thank all of the subjects who volunteered for this study. We also thank Tara Scime and Heather Campbell for their technical expertise.

Steven G. Smith is a recipient of the Father Sean O'Sullivan postdoctoral research fellowship award.

\section{Disclosure Statement}

The authors declare that they have no conflicts of interest with respect to the data presented in this paper. 


\section{References}

1 Bousquet J, Hejjaoui A, Michel FB: Specific immunotherapy in asthma. J Allergy Clin Immunol 1990;86:292-305.

2 Bousquet J, Vignola AM, Chanez P, Campbell AM, Bonsignore G, Michel FB: Airways remodelling in asthma: no doubt, no more? Int Arch Allergy Immunol 1995;107:211-214.

3 Humbles AA, Lloyd CM, McMillan SJ, Friend DS, Xanthou G, McKenna EE, et al: A critical role for eosinophils in allergic airways remodeling. Science 2004;305:1776-1779.

4 Saenz SA, Taylor BC, Artis D: Welcome to the neighborhood: epithelial cell-derived cytokines license innate and adaptive immune responses at mucosal sites. Immunol Rev 2008; 226:172-190.

5 Wong CK, Li PW, Lam CW: Intracellular JNK, p38 MAPK and NF-kappaB regulate IL25 induced release of cytokines and chemokines from costimulated $\mathrm{T}$ helper lymphocytes. Immunol Lett 2007;112:82-91.

6 Wang YH, Angkasekwinai P, Lu N, Voo KS, Arima K, Hanabuchi S, et al: IL-25 augments type 2 immune responses by enhancing the expansion and functions of TSLP-DC-activated Th2 memory cells. J Exp Med 2007;204: 1837-1847.

7 Sharkhuu T, Matthaei KI, Forbes E, Mahalingam S, Hogan SP, Hansbro PM, et al: Mechanism of interleukin-25 (IL-17E)-induced pulmonary inflammation and airways hyper-reactivity. Clin Exp Allergy 2006;36:1575-1583.

8 Ballantyne SJ, Barlow JL, Jolin HE, Nath P, Williams AS, Chung KF, et al: Blocking IL-25 prevents airway hyperresponsiveness in allergic asthma. J Allergy Clin Immunol 2007; 120: 1324-1331.

9 Saenz SA, Siracusa MC, Perrigoue JG, Spencer SP, Urban JF Jr, Tocker JE, et al: IL25 elicits a multipotent progenitor cell population that promotes $\mathrm{T}(\mathrm{H}) 2$ cytokine responses. Nature 2010;464:1362-1366.

10 Cheung PF, Wong CK, Ip WK, Lam CW: IL25 regulates the expression of adhesion molecules on eosinophils: mechanism of eosinophilia in allergic inflammation. Allergy 2006; 61:878-885.

11 Wong CK, Cheung PF, Ip WK, Lam CW: Interleukin-25-induced chemokines and interleukin-6 release from eosinophils is mediated by $\mathrm{p} 38$ mitogen-activated protein kinase, $\mathrm{c}$ Jun $\mathrm{N}$-terminal kinase, and nuclear factorkappaB. Am J Respir Cell Mol Biol 2005;33: 186-194.
12 Gaffen SL: Structure and signalling in the IL17 receptor family. Nat Rev Immunol 2009;9: 556-567.

13 Tang W, Smith SG, Beaudin S, Dua B, Howie K, Gauvreau G, et al: IL-25 and IL-25 receptor expression on eosinophils from subjects with allergic asthma. Int Arch Allergy Immunol 2014;163:5-10.

14 Angkasekwinai P, Park H, Wang YH, Wang $\mathrm{YH}$, Chang SH, Corry DB, et al: Interleukin 25 promotes the initiation of proallergic type 2 responses. J Exp Med 2007;204:1509-1517.

15 Wang W, Fan YQ, Lv Z, Yao XJ, Wang W, Huang KW, et al: Interleukin-25 promotes basic fibroblast growth factor expression by human endothelial cells through interaction with IL-17RB, but not IL-17RA. Clin Exp Allergy 2012;42:1604-1614.

16 Standardization of Spirometry, 1994 Update. American Thoracic Society. Am J Respir Crit Care Med 1995; 152:1107-1136.

17 Cockcroft DW, Killian DN, Mellon JJ, Hargreave FE: Bronchial reactivity to inhaled histamine: a method and clinical survey. Clin $\mathrm{Al}-$ lergy 1977;7:235-243.

18 O’Byrne PM, Dolovich J, Hargreave FE: Late asthmatic responses. Am Rev Respir Dis 1987; 136:740-751.

19 Terrier B, Bieche I, Maisonobe T, Laurendeau I, Rosenzwajg M, Kahn JE, et al: Interleukin-25: a cytokine linking eosinophils and adaptive immunity in Churg-Strauss syndrome. Blood 2010;116:4523-4531.

20 Sehmi R, Wardlaw AJ, Cromwell O, Kurihara K, Waltmann P, Kay AB: Interleukin-5 selectively enhances the chemotactic response of eosinophils obtained from normal but not eosinophilic subjects. Blood 1992;79:29522959.

21 Smith SG, Imaoka H, Punia N, Irshad A, Janssen LL, Sehmi R, et al: The Effect of PPAR Agonists on the Migration of Mature and Immature Eosinophils. PPAR Res 2012;2012: 235231.

22 Fort MM, Cheung J, Yen D, Li J, Zurawski SM, Lo S, et al: IL-25 induces IL-4, IL-5, and IL-13 and Th2-associated pathologies in vivo. Immunity 2001;15:985-995.
23 Hurst SD, Muchamuel T, Gorman DM, Gilbert JM, Clifford T, Kwan S, et al: New IL-17 family members promote Th1 or Th2 responses in the lung: in vivo function of the novel cytokine IL-25. J Immunol 2002;169: 443-453.

24 Jung JS, Park BL, Cheong HS, Bae JS, Kim JH, Chang HS, et al: Association of IL-17RB gene polymorphism with asthma. Chest 2009;135: 1173-1180.

25 Chang SH, Dong C: Signaling of interleukin-17 family cytokines in immunity and inflammation. Cell Signal 2011;23:1069-1075.

26 Corrigan CJ, Wang W, Meng Q, Fang C, Eid $\mathrm{G}$, Caballero MR, et al: Allergen-induced expression of IL-25 and IL-25 receptor in atopic asthmatic airways and late-phase cutaneous responses. J Allergy Clin Immunol 2011;128: 116-124.

27 Cheng D, Xue Z, Yi L, Shi H, Zhang K, Huo $\mathrm{X}$, et al: Epithelial interleukin-25 is a key mediator in Th2-high, corticosteroid-responsive asthma. Am J Respir Crit Care Med 2014;190: 639-648.

28 Carlson M, Hakansoon L, Peterson C, Stalenheim G, Venge P: Secretion of granule proteins from eosinophils and neutrophils is increased in asthma. J Allergy Clin Immunol 1991;87:27-33

29 Frigas E, Loegerine DA, Solley GO, Farrow GM, Gleich GJ: Elevated levels of the eosinophil granule major basic protein in the sputum of patients with bronchial asthma. Mayo Clin Proc 1981;56:345-353.

30 Spencer LA, Szela CT, Perez SA, Kirchhoffer CL, Neves JS, Radke AL, et al: Human eosinophils constitutively express multiple Th1, Th2, and immunoregulatory cytokines that are secreted rapidly and differentially. J Leukoc Biol 2009;85:117-123.

31 Lacy P, Rosenberg HF, Walsh GM: Eosinophil overview: structure, biological properties, and key functions. Methods Mol Biol 2014;1178:1-12.

32 Woerly G, Lacy P, Younes AB, Roger N, Loiseau S, Moqbel R, et al: Human eosinophils express and release IL-13 following CD28dependent activation. J Leukoc Biol 2002;72: 769-779.

33 Jose PJ, Griffiths-Johnson DA, Collins PD, Walsh DT, Moqbel R, Totty NF, et al: Eotaxin: a potent eosinophil chemoattractant cytokine detected in a guinea pig model of allergic airways inflammation. J Exp Med 1994;179:881887. 